\title{
ФІЛОСОФІЯ БУСІДО ЯК АНТРОПОЛОГІЯ (НА МАТЕРІАЛІ «ХАГАКУРЕ»)
}

C.В.Капранов, кандидат філософських наук, науковий співробітник Інституту філософії імені Г.С.Сковороди НАН України

Бусідо нерідко називають філософією, філософією самураїв $[1 ; 2]$. Втім, якщо розуміти філософію лише як форму дискурсивного пізнання світу, то феномен бусідо значно ширший за філософію. Цей термін дослівно означає «шлях воїна», а шлях-до (кит. дао), насамперед, передбачає праксис. Крім того, поняття бусідо в широкому розумінні означає володіння бойовими мистецтвами, знання етикету, а також майстерність у каліграфії, поезії тощо. Проте існує й теоретичний аспект «шляху самурая», виражений у класичних текстах, авторами яких є Сіба Йосімаса (1350-1410), Імагава Садайо (1325-1420), Такеда Сінген (1521-1573), Като Кійомаса (1562-1611), Дайдодзі Юдзан (1639-1730) та ін.. Багато з них були видатними воїнами або воєначальниками [3, 268-418]. На особливу увагу заслуговує Ямага Соко (1622-1685), який обгрунтував «шлях самурая» 3 позицій конфуціанства [4]. Проте найвідомішим із трактатів бусідо є «Хагакуре» («Сховане в листі») - повчання Ямамото Цунетомо (1659-1719), записані в 1709-1716 рр. його учнем Тасіро Цурамото. Навіть після скасування станових привілеїв самураїв на початку доби Мейдзі (1868-1912) традиція бусідо не перервалася, про що свідчать такі широковідомі праці XIX - XX ст., як «Бусідо - душа Японії» Нітобе Інадзо (1862-1933), написана 1899 р. [5], та «Вступ до Хагакуре» («Хагакуре нюмон») Місіми Юкіо (1925-1970), написаний 1967 р. [6, 203-312].

Об'єктом нашого дослідження $є$ саме теоретичний аспект «шляху воїна». Ми розглядаємо його у цій статті як єдину традицію, що включає як середньовічні, так і сучасні праці; з цього погляду, Мiсіма, останній видатний мислитель бусідо, $є$ повноправним ії представником. Більшість дослідників феномену самурайства (наприклад, В.Рубель, О.Коваленко, О.Бенеш, С.Тернбул $[7 ; 8 ; 9 ; 10])$ зосереджують увагу на його історичних аспектах; нас, натомість, цікавить філософський вимір бусідо. Це значить, що ми не будемо 
приділяти увагу, наприклад, питанням, наскільки ідеали бусідо відповідали реальній поведінці самураїв японського середньовіччя, або яким чином соціальні умови доби Едо (1603-1868) вплинули на розвиток «шляху воїна». Нас цікавить інше - чи дійсно бусідо у певному аспекті можна вважати філософією, і якщо так, то який ії зміст.

Бусідо, насамперед, є частиною релігійно-філософської культури Японії. Його корені можна знайти у міфології - у хроніках «Кодзікі» та «Ніхонгі», переказах про Сусаноо-но мікото, першого імператора Дзімму, богатиря Ямато Такеру тощо [11, 58-60; 12, 35-45, 68-77; 13, 140-144, 177-194, 235-252]. На формування теоретичних засад «шляху воїна» вплинули конфуціанство та буддизм (зокрема, школа дзен) [5, 11-20]. У середньовічній Японії були добре відомі праці китайських стратегів (бін изя), насамперед, засновника цієї школи Сунь-цзи [14]. Проте, на відміну від них, вчителів бусідо (ми називаємо їх так $з$ огляду на повчальний характер більшості текстів) цікавили не стільки способи, якими можна перемогти супротивника, скільки правила поведінки та риси характеру, необхідні для істинного воїна (питання першого типу більш характерні для літератури будзюиу - «військового мистецтва», прикладом якої є трактат Міямото Мусасі «Книга п’яти кілець», написаний бл. 1645 р. [15, 2191]). Саме через це Нітобе Інадзо вважав бусідо системою етики [5, 1-10]. Місіма Юкіо знаходить в «Хагакуре» потрійну філософію філософію дії, філософію кохання і філософію життя [6, 241-246].

За Ямамото Цунетомо, слідування бусідо веде до «дивовижної мудрості» (фусіті-но ціе), незалежно навіть від природжених здібностей («Хагакуре» 1:4; усі посилання на оригінал цього тексту тут і нижче за [16]). Таким чином, бусідо цілком можна назвати «філософією» у первинному розумінні цього слова - любов'ю або прагненням до мудрості. Як вважав П. Адо, антична філософія включала в себе не лише філософський дискурс, а й певний спосіб життя, що передбачав і особливі духовні вправи, причому спосіб життя був важливіший за дискурс [17, 225-228, 234-235]. Подібним чином і бусідо - це, насамперед, особливий спосіб життя, у тому числі - плекання певних чеснот за допомогою духовних вправ; але це також і дискурс, представлений текстами. Отже, з цього погляду бусідо, попри всі свої специфіки, відповідає античним уявленням про філософію.

Який же зміст цієї філософії? Ми майже не знайдемо в трактатах бусідо обговорення метафізичних або натурфілософських проблем. 
Зазвичай там сказано, що самурай має шанувати богів (камі) та будд, але про природу їх не йдеться. Мудрість, до якої веде «шлях воїна», - це мудрість у розумінні Конфуція, тобто знання людей, що підтверджує Сіба Йосімаса: «Чоловік, чия професія - війна, повинен упокорити свій розум і вдивитися у глибини інших людей. У цьому й буде полягати найвище з воєнних мистецтв» [3, 291].

Отже, у філософському плані бусідо можна розглядати як своєрідну філософську антропологію. Що ж можуть нам сказати про людину, іiі природу, смисл іiі життя тощо вчителі «шляху воїна». У межах цієї статті ми зосередимося на трактаті «Хагакуре» та вступі до нього Місіми. «Хагакуре» ми обрали як найвідоміший теоретичний текст бусідо. До того ж, як вважає Місіма, автор цього трактату - Ямамото Цунетомо - «глибоко проникнув у таємниці людського життя і зрозумів, що людина живе не лише своїм власним життям. Він знає, наскільки парадоксальна людська природа. Щойно людина здобула свободу, вона вважає себе обтяженою нею. Щойно людина отримує забезпечене життя, воно стає для неї нестерпним» $[6,225]$.

У центрі уваги вчителів бусідо не людина взагалі, а людина певного типу - людина-воїн, або, у термінах західної культури, homo militans aбо homo bellator $[18,7 ; 19,292]$. Виокремлення такого людського типу поряд із homo religiosus, homo faber, homo ludens тощо цілком виправдане, адже війна - так само питомо людський феномен, як релігія, творчість або гра. У ситуації, в якій сьогодні опинилася Україна, дослідження феномену війни i homo militans є особливо актуальними не лише з академічного погляду.

Особливістю екзистенціальної ситуації воїна $є$ постійна присутність смерті. У житті селянина смерть - частина природного циклу; у житті ремісника чи торговця - це зовнішній чинник, прикрий випадок [20]. Їхнє життя присвячене створенню й накопиченню матеріальних цінностей, воно $є$ ілюзорним запереченням смерті. Смерть від них прихована, вона завжди несподівана. Вона не $\epsilon$ частиною їхнього Шляху: коли селянин, ремісник чи торговець помирає, він уже не є селянином, ремісником чи торговцем. А воїн (самурай) є воїном саме в момент смерті, смерть - невід'ємна частина його Шляху-Дао. Тому він завжди перебуває в іiі присутності, він свідомий эiі (представники інших станів, щоб усвідомити свою смертність, мають вийти за межі свого Дао - перестати бути собою).

Тож не дивно, що смерть - одна $з$ центральних тем у бусідо. 
У «Хагакуре» (1:2) сказано: «[Я] осягнув, що шлях самурая - це смерть» (Бусідо то іу ва, сіну кото то міиукетарі) (пор. рос. переклад: $[6,7])$. I далі Ямамото Цунетомо радить робити своєрідну духовну вправу: самурай повинен щодня, вранці і ввечері, готувати себе до смерті і навчитися жити так, наче тіло його вже померло. Попри всі відмінності між культурами, вражає подібність цього твердження до розуміння філософії як підготовки до смерті у Платона: «Ті, що по-справжньому присвятили себе філософії, розмірковують, власне, про одне - про вихід із життя і смерть» (Федон, $64 a[21,240])$. Роздуми про смерть відігравали важливу роль також у практиках стоїків та епікурейців [17, 250-260]. В цьому контексті доречно згадати й Sein zum Tode («буття в напрямку смерті») Гайдеггера [22, 234-266].

Усвідомлення смерті вчить мудрості. Місіма твердить, що, на відміну від самураїв старих часів, «ми не вміємо видобувати зі смерті іiі благодатну суть і змушувати іiі працювати на нас» [6, 231]. Натомість «присутність смерті на рівні свідомості є важливою умовою душевного здоров'я» $[6,232]$. Усі знають, що людина смертна, але лише самурай цілковито усвідомлює це і тому в критичну мить виявляється готовим до смерті.

Більше того, за Ямамото Цунетомо, у ситуації «життя або смерть» самурай обирає смерть (Хагакуре, 1:2). Це, звісно, не означає, що кожен, хто прочитав ці рядки, повинен негайно вчинити самогубство. Стаючи на Шлях Воїна, людина вже тим самим робить вибір на користь смерті. «Обрати смерть» означає піти на війну, а не стати дезертиром; прийняти бій, а не ухилитися від нього. Вибір смерті - це подолання страху смерті. Проте тема самогубства також присутня у бусідо: готовність самурая до смерті кристалізується в акті сеппуку (харакірі) - ритуалізованого самогубства шляхом розрізання черева (саме так закінчив своє життя Місіма Юкіо). Оскільки інстинкт самозбереження й викликаний ним страх смерті $є$ наймогутнішим проявом тваринного начала в людині, здатність до самогубства шляхом сеппуку свідчить про подолання цього інстинкту й вихід на вищий рівень існування.

Присутність смерті призводить до переоцінки цінностей. Самурай усвідомлює, що життя - марнота марнот. «Чи не схожа людина на майстерно зроблену ляльку? ... Дійсно, цей світ - марний. А про це забувають» (Хагакуре, 2:246). Внаслідок цієї переоцінки людина починає «ставитися легко до важливих справ і серйозно - 
до незначних» (Хагакуре, 1:46), тобто, за поясненням Місіми, приділяти увагу дрібницям, від яких може залежати життя [6, 258].

У цьому примарному театрі маріонеток реальною $є$ тільки мить, яку позначає слово «зараз». Саме присутність смерті розкриває важливість поточного моменту - вона вимагає жити тут і зараз, а не минулим чи майбутнім. Цього вчить воїна його бойовий досвід: усе вирішує «ось ця» мить. Ямамото Цунетомо формулює це таким чином: «Насправді немає нічого, крім єдиної думки теперішньої миті (іма-но іцінен). Такі моменти, йдучи один за одним, становлять життя. Якщо це добре зрозуміти, то нема більше про що клопотатися, нема чого прагнути. Лише живи й зберігай вірність єдиній думці цієї-ось миті ... У єдиній думці цієї-ось миті міститься і відданість» (Хагакуре, 2:213).

Місіма твердить, що «Хагакуре» вчить свободі і пристрасті [6, 207]. На його думку, смерть пов'язана зі свободою: «Формула «смерть - це свобода» ідеально пасує самураю» $[6,250]$. Це твердження лише на перший погляд є парадоксальним: ставлячи людину перед вибором «життя чи смерть», бусідо окреслює простір людської свободи, адже смерть - iї межа, оскільки задає іiі абсолютні межі: якщо зняти всі заборони, людина може робити все, що завгодно, крім того, що її вб'є. Водночас думка про смерть дає усвідомлення швидкоплинності сущого, яке робить людину вільною: «Життя людини воістину триває всього лише мить, тому живи, роблячи те, що хочеш. Нерозумно жити в цьому світі, подібному до сновидіння, щодня зустрічатися з неприємностями й робити те, що тобі не подобається〉 (Хагакуре, 2:287). Місіма небезпідставно вважає цю думку Ямамото Цунетомо епікурейською $[6,297]$ - вона дійсно перегукується з думками Епікура та його послідовників, які, за висловом П.Адо, «на кожну мить дивилися 3 точки зору смерті як на чарівний подарунок» [17, 257].

Присутність смерті розкриває підступну роль розуму, оскільки розумування приховують смерть від людини. Згідно з Ямамото Цунетомо, «люди, що звикли все розраховувати, гідні зневаги. I це тому, що розрахунки завжди грунтуються на розмірковуваннях про втрату або здобуток, а цим міркуванням немає кінця. Смерть вважають за втрату, а життя - за здобуток. Тому такій людині не подобаються думки про смерть...» (Хагакуре, 1:111). 3 цього погляду, навіть вченість може бути шкідливою для самурая, адже нерідко «вчені люди за розумуваннями й розмовами приховують 
своє боягузтво й жадібність» (Хагакуре, 1:111). Розважливості Ямамото Цунетомо протиставляє шалений порив: «У здоровому глузді ніколи не здійснити великих справ. Треба просто стати шаленим і без тями кинутися назустріч смерті» (Хагакуре, 1:113). В оригіналі тут використано слово сінігуруй, що можна перекласти як «одержимий смертю».

Проте у «Прихованому в листі» можна знайти й прямо протилежні думки: «Бусідо полягає в тому, щоб, розуміючи, що сьогоднішній день нам ще невідомий, днями й ночами ретельно вивчати кожну можливість» (Хагакуре 1:55). В іншому місці Ямамото Цунетомо твердить, що нетерплячість лише шкодить справі, і закликає міркувати про те, що буде через п'ятнадцять років (Хагакуре 2:332). Місіма згадує, що саме завдяки цій книзі навчився складати детальний план з вечора на наступний день [6, 253]. Отже, думкам «Прихованого в листі» властива парадоксальність: щоб бути здатним діяти саме цієї миті, треба готуватися заздалегідь, і водночас кожної миті треба жити саме тут і зараз; треба бути терплячим i шалено рішучим. Цих якостей вимагає від воїна його доля - війна.

Бусідо не може оминути питання про смисл війни. 3 одного боку, цьому напрямку думки чужа ідея боротьби за виживання самурай не бореться за місце під сонцем, за ласий шматок. Той, хто йде в бій заради здобичі, - не воїн, а розбійник. 3 іншого боку, бусідо чуже й маніхейське уявлення про боротьбу абсолютного добра $з$ абсолютним злом. Ямамото Цунетомо застерігає проти спрощеного розуміння шляху самурая: «Боротися 3 несправедливістю й обстоювати справедливість складно. Проте, якщо вважаєш, що необхідно понад усе стояти за справедливість, навпаки, наробиш чимало помилок саме щодо справедливості. Понад справедливістю $\epsilon$ Шлях-Дао. (...) 3 такого погляду, справедливість і т.ін. є дрібницями» (Хагакуре, 1:44). Втім, самурай має етичну місію: «Все, що ти робиш, ти маєш робити заради свого пана і батька, заради всіх людей, заради дітей і онуків. Це і є Велике Співчуття (дайдзіхі). Мудрість і сміливість, які походять зі співчуття, є справжніми. ... Робити щось для себе дріб'язково й негідно» (Хагакуре, 1:178).

Смисл життя людини, за бусідо, - служіння. Слово «самурай» етимологічно означає «той, хто служить» (зауважимо, що латинське militare, крім значення «воювати», також має і значення «служити»). Світ бусідо - ієрархічний, кожен посідає в цій ієрархії відведене йому місце. Служіння полягає у цілковитій відданості князю-даймьо 
(сюзерену, сюкун) з боку васала (керай), що докладно описано в «Хагакуре» $(1: 3,1: 9$ тощо). Переклад згаданих термінів відповідно як «пан» і «слуга», як прийнято в російських виданнях [3; 6], викривляє картину, адже йдеться не про звичайного слугу, а про шляхтича - самурая. Його служіння князеві жодним чином не принижує гідності, яка для самурая має велике значення. Проте і князь - теж самурай, його обов'язок - дбати про васалів, як про своїх дітей (Хагакуре, 1:178). Він також знаходить смисл свого життя у служінні своєму клану. У служінні клану князь і його васал об'єднуються, протилежність між ними знімається.

У бусідо можна виділити два аспекти служіння: відносний, оскільки у кожного самурая - свій клан, свій князь; і абсолютний повна відданість, у перспективі - не важливо, кому саме служить самурай. Служіння пов'язане зі смертю не лише тому, що воїн має бути готовим будь-якої миті загинути за свій клан або здійснити сеппуку, а й тому, що ідеальний самурай служить так, наче тіло його вже мертве («Хагакуре» 1:7). Служіння у своєму абсолютному аспекті, отже, означає подолання себе, свого егоїзму, індивідуалістичної обмеженості.

Самурай традиційної доби закорінений у своєму клані. У «Вечірній розмові» (есеї, який включають до «Хагакуре» як додаток), Ямамото Цунетомо - попри те, що він уже був на той час буддійським монахом, - висловлює сподівання, що в наступному житті не стане буддою; натомість він бажає сім разів народитися самураєм клану Набесіма [23]. У добу Мейдзі (1868-1912 рр.) кланова структура і станові привілеї були скасовані, проте принципи бусідо були перенесені на всю націю: об'єктом служіння стала Японія, уособлена імператором як єдиним і найвищим сюзереном. Скасування станових привілеїв зробило ці принципи загальнонаціональними. Патріотизм, любов до батьківщини замінили відданість клану й сюзерену.

Отже, антропологічна складова бусідо аж ніяк не зводиться до проповіді «феодальної моралі» чи примітивного фанатизму. В іiі основі - складне і глибоке розуміння людини, яке цілком можна назвати «філософським». 


\section{ЛІТЕРАТУРА}

1. Honor: Samurai Philosophy of Life. - Bottom of the Hill, 2010. $-218 \mathrm{p}$.

2. Цыљыпов А.С. Философия самураев: тема смерти - Б.м., 2010. - 10 с. // filosof10.narod.ru/lib/Filosofia/samurai.docx

3. Кодекс Бусидо. Хагакурэ. Сокрытое в листве. - М., 2005. - 432 с.

4. Торнтон С.А. Ямага Соко // Великие мудрецы Востока. - М., 1999. C. 459-464.

5. Nitobe Inazo. Bushido: The Soul of Japan. - Rutland and Tokyo: Charles E. Tuttle, 1995. - $204 \mathrm{p}$.

6. Ямамото Цунэтомо. Хагакурэ. Юкио Мисима. Хагакурэ нюмон. Самурайская этика в современной Японии. - СПб., 1996. -330 с.

7. Рубель В.А. Походження військово-самурайської державності у традиційній Японії (середина I тис. до н.е. - XIV ст. н.е.) : автореф. дис. на здобуття наук. ступеня докт. іст. наук. - К., 1999. - 39 с.

8. Коваленко О. Самурайські хроніки: Ода Нобунага. - К., 2013. - 960 с.

9. Benesh $O$. Inventing the Way of the Samurai. - Oxford: Oxford University Press, 2014. - 284 p.

10. Тернбулл С. Армии самураев, 1550-1615. - М., 2005. - 61 с.

11. Кодзики - Записи о деяниях древности. Свиток 1-й. Мифы. - СПб., 1994. $-320 \mathrm{c}$.

12. Кодзики - Записи о деяниях древности. Свитки 2-й и 3-й. - СПб., 1994. $-256 \mathrm{c}$.

13. Нихон сёки - Анналы Японии. Т. 1. - СПб., 1997. - 496 с.

14. Сунь-дзи. Мистецтво війни. - Львів, 2015. - 110 с.

15. Миямото Мусаси. Книга Пяти колец: Трактаты. - СПб., 2004. - 256 с.

16. Хагакуре гембун Web // http://hagakure-text.jp

17. Адо П. Що таке антична філософія? - К., 2014. - 428 с.

18. Langan T., Calcagno A. Human Being: A Philosophical Anthropology. Columbia and London: University of Missouri Press, 2009. - 216 p.

19. Nycz $R$. Język modernizmu: Problemy historzczno-literackie. - Torun: Wzdawnictwo Naukowe Uniwersztetu Mikołaja Kopiernika, 2013. - 334 s.

20. У Японії доби Токугава (часів написання більшості трактатів з бусідо) суспільство поділялося на чотири стани - воїни (самураї), селяни, ремісники і торговці.

21. Платон. Діалоги. - К., 1999. - 395 с.

22. Хайдеггер М. Бытие и время. - М., 1997. - 452 с.

23. Яін-но кандан // http://hagakure-text.jp/preface/2.html 
Капранов С.В. Філософія бусідо як антропологія (на матеріалі «Хатакуре»).

У статті розглядаються антропологічні аспекти японського вчення «шляху воїна» (бусідо). Обгрунтовується правомірність історико-філософського підходу до вивчення бусідо як філософської антропології, у центрі якої - тип людини-воїна (homo militans). Проаналізовано основні екзистенціали бусідо - смерть, свободу, служіння.

Ключові слова: антропологія, японська філософія, філософія війни, бусідо, самураї.

Капранов С.В. Философия бусидо как антропология (на материале «Хатакуре»).

В статье рассматриваются антропологические аспекты японского учения «пути воина» (бусидо). Обосновывается правомерность историкофилософского подхода к изучению бусидо как философской антропологии, в центре которой - тип человека-воина (homo militans). Анализируются основные экзистенциалы бусидо - смерть, свобода, служение.

Ключевые слова: антропология, японская философия, философия войны, бусидо, самураи.

Kapranov S.V. The philosophy of Bushido as anthropology (based on «Harakure»).

In the article, anthropological aspects of the Japanese «Way of the Warrior» (Bushido) are considered. The author tries to substatiate appropriateness of philosophical approach to Bushido as a kind of philosophical anthropology, focused upon warrior as a type of human being (homo militans). For the analysis, the well-known treatise on Bushido - Hagakure («Hidden by the leaves»), together with an introduction to it, Hagakure nyumon by Mishima Yukio, are chosen. The basic existentials of Bushido - death, freedom, service - are analyzed as well. Death is the central topic of Bushido anthropology, and it is related to both freedom and service.

Key words: anthropology, philosophy Japanese philosophy of war, Bushido, the samurai 